\title{
The Geo-accumulation Index of Some Heavy Metals in the Roadsides Soils of Onitsha South Local Government Area Anambra State, Nigeria
}

\author{
Ochiagha K. E. ${ }^{1,}$, Okoye P. A. C. ${ }^{2}$, Eboagu N. C. ${ }^{2}$ \\ ${ }^{1}$ Department of Pure and Industrial Chemistry, Faculty of Physical Sciences, Nnamdi Azikiwe University, Awka, Nigeria \\ ${ }^{2}$ Department of Pure and Industrial Chemistry, Nnamdi Azikiwe University, Awka, Nigeria
}

Email address:

kateochiagha@gmail.com (Ochiagha K. E.), pacnau052@yahoo.com (Okoye P. A. C.), nc.eboagu.unizik.edu.ng (Eboagu N. C.)

${ }^{*}$ Corresponding author

\section{To cite this article:}

Ochiagha K. E., Okoye P. A. C., Eboagu N. C. The Geo-accumulation Index of Some Heavy Metals in the Roadsides Soils of Onitsha South Local Government Area Anambra State, Nigeria. Science Journal of Chemistry. Vol. 8, No. 3, 2020, pp. 42-47.

doi: $10.11648 /$ j.sjc. 20200803.11

Received: February 11, 2020; Accepted: April 1, 2020; Published: April 28, 2020

\begin{abstract}
Heavy metals have a great ecological significance due to their toxicity and accumulative behaviour. Monitoring of their concentrations in the soils of our environment is very important. The geo-accumulation index (Igeo) in 11 stations in Onitsha South Local Government Area, (i.e Modeebelu Avenue, Ozomagana, Zik Avenue, Port Harcourt Road, Oguta Road, Iweka Road, Venn Road, Niger Street, Creek /Okwaraji Moore Street and Bida Road) were analysed. The soil pollution status of the area was investigated by analyzing the concentration of eight heavy metals $(\mathrm{Mn}, \mathrm{Ni}, \mathrm{Zn}, \mathrm{Cd}, \mathrm{Cr}, \mathrm{Fe}, \mathrm{Cu}$ and $\mathrm{Pb}$ ) using Atomic Absorption spectroscopy (AAS). From the geo-accumulation index $\left(\mathrm{I}_{\mathrm{geo}}\right)$ results obtained were; Mn values were mainly in class 5 for wet season and class 4 in dry season, $\mathrm{Ni}$ fell within the range of classes 2-3 in both seasons, $\mathrm{Zn}$ was in the range of classes 1-2 while $\mathrm{Cr}$ fell within the ranges of class 4-5 for both seasons. $\mathrm{Cu}$ was mainly within the range of class $2-3$ in both seasons, while $\mathrm{Pb}$ fell within class 0 (with the exception of few locations). The Fe geo-accumulation for all locations was within the class of 0 . These results revealed that $\mathrm{Fe}, \mathrm{Cd}$ and $\mathrm{Pb}$ did not pollute the area but were polluted by $\mathrm{Mn}, \mathrm{Cr}, \mathrm{Zn}$ and $\mathrm{Ni}$ at various levels in both seasons.
\end{abstract}

Keywords: Geo-accumulation Index, Heavy Metals, Pollution, Onitsha South LGA

\section{Introduction}

Heavy metals accumulation in soils, sediments and their subsequent release to ground or surface water poses an environmental threat [1]. Onitsha being densely populated and heavily commercialized has several activities that go on in it that leads to constant discharge of heavy metals into the environment especially the soil. Such activities include vehicular emission, indiscriminate waste disposal and industrial effluents. The toxicity of some of these heavy metals especially to the living tissues causing a lot of damages should not be overlooked. This necessitated the study of this area.

Heavy metal pollution is widespread in different terrestrial system in Nigeria. Soils constitute the largest heavy metals reservoir in terrestrial systems. The extent of heavy metals contamination in the soil or other media is dependent on their sources, redox conditions, microbial activities and the physicochemical properties of solid and aqueous phases [2]. Once accumulated in soils, the metals continue to pose a threat to life due to their accumulation in soil and through food chain transfer, including organo-elements. Heavy metals may also enter into aquatic ecosystems from anthropogenic sources, such as industrial waste water discharges, sewage waste water, fossil fuel combustion and atmospheric deposition [3, 4 \& 5]

To gauge the degree of anthropogenic influence on heavy metals concentration in the soil, geo-accumulation index is used (I geo). Generally, the $\mathrm{I}_{\text {geo }}$ consists of 7 grades or classes (Table 1). As defined by Müller, 1979, the geo-accumulation index is a quantitative measure of metal pollution. This assessment index was cited by studies in soils and sediments [6] and [7]. $I_{\text {geo }}$ values are calculated using the following mathematical formula:

$$
I_{\text {geo }}=\log _{2}\left(\frac{C n}{1.5 X B n}\right)
$$


Where $C_{n}$ is the measured content of element, and $B_{n}$ is the background or pristine value of the element. The constant factor 1.5 is the background matrix correction factor due to lithogenic effects in (1) above.

\section{Experimental}

\subsection{Collection and Preparation of Samples}

Soil samples from roadside in eleven streets (Odoakpu, woliwo and Fegge areas) were collected using plastic container to transfer them into different labeled polyethene bags. They were investigated for total heavy metal contents and speciation.

A total of five roadside soil sediment samples (grab samples) were collected from each of the eleven streets, where the gap of sampling sites for each street was a distance of $50 \mathrm{~m}$ apart (electric pole distance). Sampling was carried out in two seasons; dry season (February) and rainy season (August). The collection of the grab samples was done using a plastic grab sampler (plastic parker) and kept in a black polyethene bag for onward transportation to the laboratory. In general, five grab soil sediment samples were collected from the gross composite samples, a representative of the soil sample for each street. $10 \mathrm{~g}$ of each grab soil sample was measured from a particular street to form a laboratory sample and kept for the analysis.

The samples were air-dried at room temperature in the laboratory. Large objects and stones were removed index mechanically. Each street representative sample was ground thoroughly using mortar and pestle to obtain a homogeneous mixture sample for each street. The soil samples were then sieved through a mesh screen to obtain homogeneous particle size $(<600 \mu \mathrm{m})$. The soil samples finer than $600 \mu \mathrm{m}$ were collected in a black polyethene bag for the laboratory analysis.

\subsection{Total Metal Digestion}

The digestion for the total metal determination was carried out in polytetrafluoroethylene (PTFE) beaker. $1.0 \mathrm{~g}$ of the dried soil sample was accurately weighed into a clean and dry Teflon beaker. A mixture of $5 \mathrm{~mL} \mathrm{HF}$ and $5 \mathrm{~mL}$ aqua-regia (all analar grades) were added and the acids-soil mixtures digested in a water bath at $100^{\circ} \mathrm{C}$ for $1.5 \mathrm{~h}$ with subsequent addition of second sets of $5 \mathrm{~mL} \mathrm{HF}$ and $5 \mathrm{~mL}$ aqua-regia and this lasted for another $1.5 \mathrm{~h}$ for complete digestion. The resulting solutions were cooled at room temperature, followed by careful addition of saturated boric acid $\left(\mathrm{H}_{3} \mathrm{BO}_{3}\right)$. The boric acid was to form complex with any residual $\mathrm{HF}$, which would otherwise attack glass wares. The digested solutions were filtered into $100 \mathrm{~mL}$ standard flasks using Whatman No. 1 filter paper. The solutions were made up to mark of $100 \mathrm{~mL}$ with deionized water in the container after rinsing with deionized water. This was then stored for the Atomic Absorption Spectrophotometer (AAS) analysis. The digestion processes were repeated for all the other samples. The blank was also prepared. Both the digested solutions and the blank were analyzed for the presence of the following metals, $\mathrm{Fe}, \mathrm{Mn}, \mathrm{Cd}, \mathrm{Cr}, \mathrm{Cu}, \mathrm{Ni}, \mathrm{Zn}$ and $\mathrm{Pb}$ using AAS.

\subsubsection{Determination of Geo-accumulation Index}

The determination of geo-accumulation index was done using (1) above. The values that were obtained from mean metal concentration were used while the background values for the eight metals studied were Mn (0.051), Ni (0.222), Zn (0.428), $\mathrm{Cr}$ (0.381), $\mathrm{Cu}$ (0.126), Pb (0.134) and $\mathrm{Fe}$ (269) for wet season; $\mathrm{Mn}$ (0.131), Ni (0.362), Zn (0.618), Cr (0.389), $\mathrm{Cu}(0.170), \mathrm{Pb}(0.361)$ and $\mathrm{Fe}(380)$ in $\mathrm{mg} / \mathrm{kg}$ for dry season.

Table 1. Classification of geo-accumulation index [3].

\begin{tabular}{lll}
\hline Classification & $\mathbf{I}_{\text {geo }}$ & Pollution status \\
\hline 0 & $\mathrm{I}_{\text {geo }}<0$ & Unpolluted \\
1 & $0<\mathrm{I}_{\text {geo }} \leq 1$ & Unpolluted to moderately polluted (UMP) \\
2 & $1<\mathrm{I}_{\text {geo }} \leq 2$ & Moderately polluted (MP) \\
3 & $2<\mathrm{I}_{\text {geo }} \leq 3$ & Moderately to strongly polluted (MSP) \\
4 & $3<\mathrm{I}_{\text {geo }} \leq 4$ & Strongly polluted (SP) \\
5 & $4<\mathrm{I}_{\text {geo }} \leq 5$ & Strongly to extremely polluted (SEP) \\
6 & $5<\mathrm{I}_{\text {geo }} \leq 6$ & Extremely polluted (EP) \\
\hline
\end{tabular}

$\mathrm{I}_{\text {geo }}=$ geoaccumulation

\subsubsection{Correlation Analysis}

The correlation analysis was selected to identify the possible pollution sources [8] and the data in this work were performed with SPSS 12.0 for Windows [9].

\subsubsection{Quality Assurance of Data}

All chemicals used were of analar grade and deionized water was used throughout the experimentation. All plastic materials used were soaked in $10 \%$ Nitric acid. Procedural blanks and preparation of standard solutions were done under clean laboratory environment, calibration of the Buck 211 Flame Atomic Absorption spectrophotometer (FAAS) using certified standards and the analysis of calibrated standards after 10 samples were conducted to ensure that the instrument remained calibrated were some of the measures taken during the experimentation.

\section{Results and Discussion}

\subsection{Description of the Study Area}

Onitsha South Local Government Area is located between latitudes $06^{\circ} 07^{\prime} 12^{\prime} \quad \mathrm{N}$ and $06^{\circ} 9^{\prime} 36^{\prime} \mathrm{N}$ and longitude $06^{\circ} 45^{\prime} 54^{\prime} \mathrm{E}$ and $06^{\circ} 47^{\prime} 42^{\prime} \mathrm{E}$ covering an area of $36.12 \mathrm{Km}^{2}$. It is bounded by Onitsha North local government area and in the east Ogbaru L. G. A. in the south and in the west by River Niger (Figure 1). Onitsha is the largest urban city in Anambra state with a population of about 561066 according to 2006 census. It is also a major commercial town east of the Niger [10].

The climate is classified as tropical region. The climate here is classified as Aw by the Köppen-Geiger system. The average annual temperature in Onitsha is $27.0^{\circ} \mathrm{C}$ with rainfall averaging $1828 \mathrm{~mm}$ with monthly relative humidity being at least $86 \%$. The area stands on a low-lying terrain with altitude ranging from $57 \mathrm{~m}$ to $59 \mathrm{~m}$ above sea level. The area is characterized by medium annual temperature, high rainfall, high evapo-transpiration and high relative 
humidity, which makes it to be classified as humid tropical region [11]. The type of soil of Onitsha south L. G. A is hydromorphic [10].

\subsection{The Total Metal Concentration and Geo-accumulation Index}

Many studies in different region of the world have used the soil as an indicator for pollution [12]. The highest concentrations of $\mathrm{Mn}, \mathrm{Ni}, \mathrm{Zn}, \mathrm{Cr}, \mathrm{Cu}, \mathrm{Pb}, \mathrm{Cd}$ and $\mathrm{Fe}$ (1.883, $2.421,1.638,12.411,1.496,0.689, \mathrm{BDL}$ and $125.150 \mathrm{mg} / \mathrm{kg}$ respectively in wet season) and 1.980, 3.222, 3.234, 17.456, $2.041,0.880, \mathrm{BDL}$ and $191.000 \mathrm{mg} / \mathrm{kg}$ respectively in dry season) were recorded in Onitsha South LGA (Tables 2 and 3).

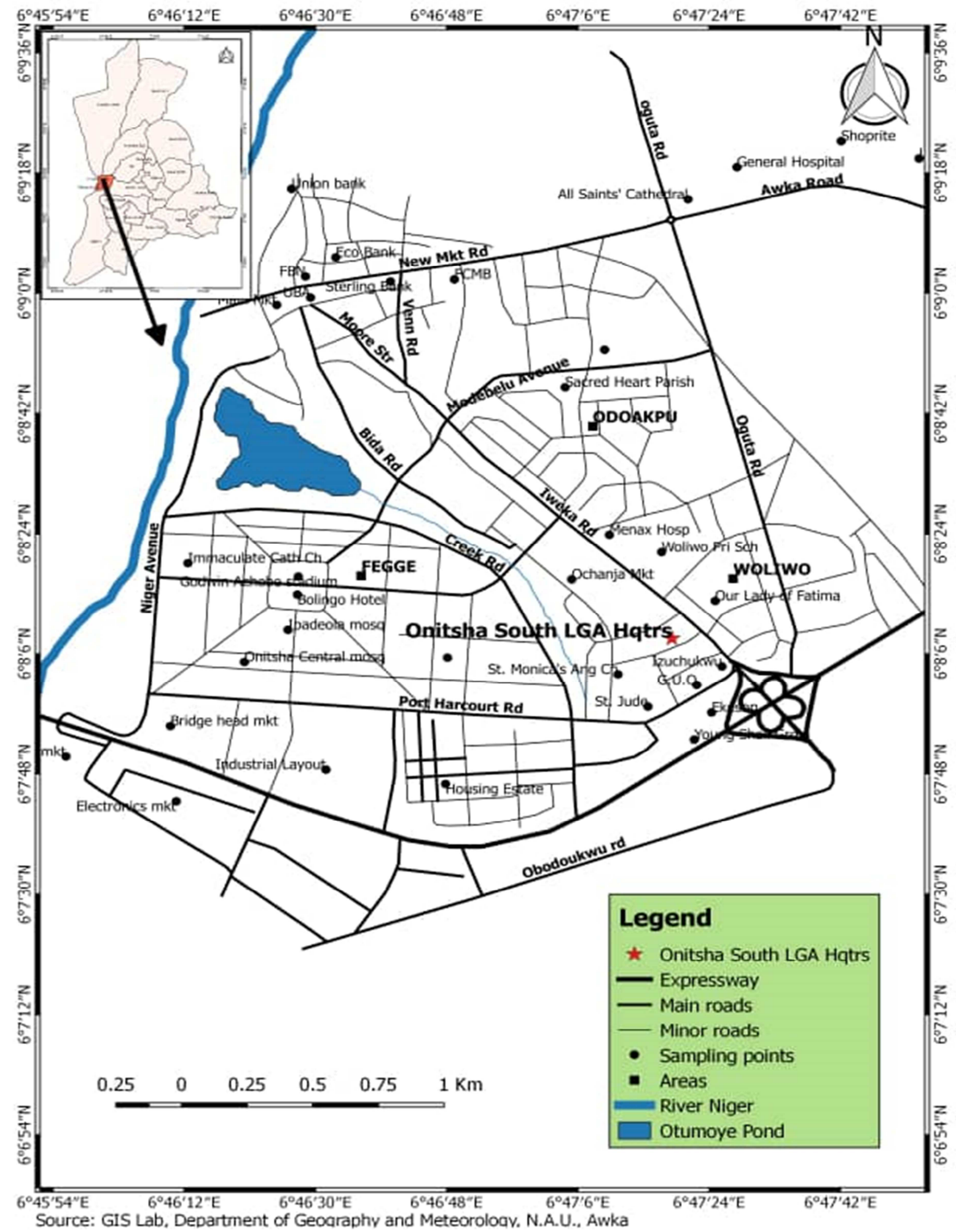

Figure 1. Map of Onitsha South Local Government Area of Anambra State. 
Table 2. Total metal concentration $(\mathrm{mg} / \mathrm{kg}) \pm(\mathrm{SD})$ in the soil for wet season.

\begin{tabular}{|c|c|c|c|c|c|c|c|c|c|}
\hline Sample Location & Mn & $\mathrm{Ni}$ & $\mathbf{Z n}$ & Cd & $\mathbf{C r}$ & $\mathbf{C u}$ & $\mathbf{P b}$ & $\mathbf{F e}$ & Mean \\
\hline Modebelu Avenue & $1.442(0.21)$ & $0.447(0.61)$ & $0.547(0.19)$ & BDL & $7.218(0.11)$ & $0.861(0.05)$ & BDL & $52.520(0.65)$ & 10.506 \\
\hline Ozomagana street & $1.821(0.16)$ & $1.600(0.40)$ & $1.638(0.41)$ & BDL & $10.593(0.03)$ & $0.519(0.28)$ & BDL & $111.917(0.81)$ & 21.341 \\
\hline Ziks Avenue & $1.821(0.61)$ & $1.361(0.66)$ & $1.477(0.57)$ & BDL & $9.126(0.83)$ & $0.531(0.09)$ & BDL & $82.542(0.88)$ & 16.143 \\
\hline Port Harcourt Road & $1.883(0.12)$ & $0.077(0.11)$ & $1.145(0.15)$ & BDL & $8.257(0.16)$ & $0.703(0.05)$ & $0.338(0.15)$ & $81.008(4.34)$ & 13.344 \\
\hline Oguta Road & $1.381(0.24)$ & $0.581(0.40)$ & $1.386(0.22)$ & BDL & $9.937(0.25)$ & $0.207(0.04)$ & $0.25(0.22)$ & $125.150(2.77)$ & 19.842 \\
\hline Iweka Road & $1.283(0.21)$ & $1.513(0.46)$ & $1.437(0.14)$ & BDL & $10.319(0.56)$ & $1.496(0.83)$ & $0.689(0.20)$ & $94.409(3.92)$ & 15.878 \\
\hline Venn Road & $0.937(0.81)$ & $1.566(0.23)$ & $1.085(0.24)$ & BDL & $11.051(0.18)$ & $\operatorname{BDL}(0.00)$ & $\mathrm{BDL}$ & $101.349(0.88)$ & 23.198 \\
\hline Creek/okwaraji Street & $0.650(0.26)$ & $1.236(0.61)$ & $1.724(0.51)$ & BDL & $6.977(0.73)$ & BDL & BDL & $89.183(0.87)$ & 19.954 \\
\hline Moore Street & $1.242(0.31)$ & $1.659(0.80)$ & $0.967(0.38)$ & BDL & $6.808(0.44)$ & $0.693(0.10)$ & BDL & $115.275(1.50)$ & 21.107 \\
\hline Bida Street & $1.086(0.56)$ & $1.201(0.83)$ & $1.489(0.89)$ & BDL & $7.228(0.04)$ & BDL & BDL & $97.475(0.65)$ & 21.696 \\
\hline Total Metal & 15.302 & 13.621 & 13.657 & 0 & 99.923 & 6.369 & 2.076 & 1060.053 & 201.399 \\
\hline Mean $( \pm$ SD $)$ & $1.391(0.404)$ & $1.238(0.655)$ & $1.205(0.374)$ & 0 & $9.084(1.916)$ & $0.759(0.435)$ & $0.519(0.266)$ & $96.368(20.060)$ & \\
\hline
\end{tabular}

$\mathrm{SD}=$ standard deviation, $\mathrm{BDL}=$ below detection limit

Table 3. Total metal concentration $(\mathrm{mg} / \mathrm{kg}) \pm(\mathrm{SD})$ in the soil for dry season.

\begin{tabular}{|c|c|c|c|c|c|c|c|c|c|}
\hline \multicolumn{10}{|c|}{ TOTAL METAL CONCENTRATION FOR DRY SEASON (mg/kg) } \\
\hline Sample location & Mn & $\mathbf{N i}$ & Zn & Cd & $\mathbf{C r}$ & $\mathrm{Cu}$ & $\mathbf{P b}$ & $\mathbf{F e}$ & Mean \\
\hline Modebelu Avenue & $1.172(0.06)$ & $1.434(0.23)$ & $1.722(0.17)$ & BDL & $10.246(0.50)$ & $1.543(0.10)$ & BDL & $83.316(0.56)$ & 16.572 \\
\hline Ozomagana street & $1.947(0.31)$ & $2.103(0.40)$ & $3.088(0.25)$ & $\mathrm{BDL}$ & $11.779(0.40)$ & $0.945(0.30)$ & $\mathrm{BDL}$ & $137.900(0.98)$ & 26.294 \\
\hline Ziks Avenue & $1.872(0.33)$ & $1.792(0.23)$ & $3.234(0.27)$ & $\mathrm{BDL}$ & $10.864(0.08)$ & $0.998(0.32)$ & $\mathrm{BDL}$ & $119.608(0.62)$ & 23.061 \\
\hline Port Harcourt Rd & $1.286(0.41)$ & $0.277(0.61)$ & $2.696(0.19)$ & BDL & $11.026(0.02)$ & $0.895(0.20)$ & $0.4160 .21)$ & $145.092(0.87)$ & 23.098 \\
\hline Oguta street & $0.768(0.06)$ & $0.868(0.23)$ & $2.173(0.36)$ & $\mathrm{BDL}$ & $12.765(0.21)$ & $0.548(0.01)$ & $0.318(0.25)$ & $136.644(0.91)$ & 22.012 \\
\hline Iweka Road & $1.026(0.37)$ & $1.927(0.23)$ & $2.082(0.19)$ & BDL & $10.936(0.20)$ & $2.041(0.43)$ & $0.880(0.32)$ & $148.708(0.19)$ & 23.943 \\
\hline Venn Road & $1.841(0.47)$ & $1.873(0.40)$ & $2.578(0.11)$ & $\mathrm{BDL}$ & $17.456(0.10)$ & $\mathrm{BDL}$ & $\mathrm{BDL}$ & $150.550(1.09)$ & 34.860 \\
\hline Niger Street & $1.951(0.65)$ & $3.222(0.05)$ & $2.566(0.27)$ & $\mathrm{BDL}$ & $13.988(0.03)$ & $1.510(0.78)$ & $0.994(0.26)$ & $149.558(0.89)$ & 24.827 \\
\hline Creek/okwaraji Street & $1.980(0.12)$ & $1.981(0.69)$ & $2.072(0.28)$ & $\mathrm{BDL}$ & $7.973(0.30)$ & BDL & $0.119(0.67)$ & $191.000(0.71)$ & 34.188 \\
\hline Moore Street & $1.834(0.10)$ & $2.487(0.46)$ & $2.169(0.18)$ & BDL & $9.075(0.10)$ & $1.237(0.23)$ & $0.564(0.67)$ & $176.167(0.78)$ & 27.647 \\
\hline Bida street & $1.911(0.06)$ & $2.182(0.46)$ & $2.591(0.29)$ & $\mathrm{BDL}$ & $10.876(0.11)$ & BDL & $0.206(0.50)$ & $140.433(0.98)$ & 26.367 \\
\hline Total & $17.587(0.44)$ & 20.145 & 26.971 & 0 & 126.983 & 9.717 & 3.497 & 1578.977 & 282.868 \\
\hline Mean \pm SD & $1.599(0.444)$ & $1.822(0.781)$ & $2.452(0.458)$ & 0 & $11.544(2.541)$ & $1.212(0.471)$ & $0.357(0.337)$ & $143.543(27.785)$ & \\
\hline
\end{tabular}

$\mathrm{SD}=$ standard deviation, $\mathrm{BDL}=$ below detection limit

The level of $\mathrm{Cd}$ in each season is below detectable limit. The concentration of Fe is highest in locations $9(191.00 \mathrm{mg} / \mathrm{kg})$ and $10(115.275 \mathrm{mg} / \mathrm{kg})$ in dry and rainy seasons respectively. Apart from $\mathrm{Cd}$, there is least record of concentration of $\mathrm{Pb}$ in both seasons. The concentration of $\mathrm{Mn}$ is highest in locations $4(1.883 \mathrm{mg} / \mathrm{kg})$ and $(1.980 \mathrm{mg} / \mathrm{kg})$ for rainy and dry seasons respectively, this is because most of the activities that go on in the location has the tendency of releasing $\mathrm{Mn}$, the activities include; sewage sludge, sales and handling of steels, iron etc. $\mathrm{Ni}$ had its highest concentration in locations $8(2.421 \mathrm{mg} / \mathrm{kg})$ and $10(2.487 \mathrm{mg} / \mathrm{kg})$ in rainy and dry seasons respectively. $\mathrm{Cr}$ had relatively higher value than $\mathrm{Fe}$. It had highest value in locations $8(12.41 \mathrm{mg} / \mathrm{kg})$ and $7(17.456 \mathrm{mg} / \mathrm{kg})$ in rainy and dry seasons respectively. This is attributed to the type of activities going on in the locations; examples are photographing and sale of photographic materials at Venn road and sale of alloys of iron and related building materials at Niger Street

The mean total load of all metals in each location ranges between $10.506-23.198 \mathrm{mg} / \mathrm{kg}$ rainy season and $16.572-34.86 \mathrm{mg} / \mathrm{kg}$ in dry season. The present study revealed that the lowest values of $\mathrm{Cr}, \mathrm{Pb}, \mathrm{Cu}, \mathrm{Co}, \mathrm{Ni}, \mathrm{Mn}, \mathrm{Cd}$ and $\mathrm{Fe}$ were recorded in Modebelu Avenue while and highest was recorded in Venn Road. The reason for low metal load in Modebelu Avenue might be due to fewer activities in the location due the relocation of the markets away from the street Venn Road had increased activity especially as it leads to Onitsha main market. These results agreed with those of Omuku, (2011) [13].

Geo-accumulation index $\left(I_{\text {geo }}\right)$.

Geo-accumulation indices are shown in Tables 4 and 5 for wet and dry seasons respectively.

Table 4. Geo-accumulation index classes for seven metals in wet season.

\begin{tabular}{llllllll}
\hline Location & Mn & Ni & Zn & $\mathbf{C r}$ & $\mathbf{C u}$ & $\mathbf{P b}$ & $\mathbf{F e}$ \\
\hline Modebelu Avenue & 5 & 1 & 0 & 4 & 3 & 0 & 0 \\
Ozomagana & 5 & 3 & 2 & 4 & 2 & 0 & 0 \\
Ziks Avenue & 5 & 3 & 2 & 4 & 2 & 0 & 0 \\
Port Harcourt Rd & 5 & 0 & 1 & 4 & 2 & 1 & 0 \\
Oguta Rd & 5 & 1 & 2 & 5 & 1 & 1 & 0 \\
Iweka Rd & 5 & 3 & 2 & 5 & 3 & 2 & 0 \\
Venn Rd & 4 & 3 & 1 & 5 & 0 & 0 & 0 \\
Niger Street & 5 & 3 & 1 & 5 & 3 & 2 & 0 \\
CreekOkwaraji street & 4 & 2 & 2 & 4 & 0 & 0 & 0 \\
Moore street & 5 & 3 & 1 & 4 & 2 & 0 & 0 \\
Bida Rd & 4 & 2 & 2 & 4 & 0 & 0 & 0 \\
Mean & 5 & 2 & 1 & 4 & 2 & 1 & 0 \\
\hline
\end{tabular}

$\mathrm{I}_{\mathrm{geo}}=$ geoaccumulation index for wet season

The $\mathrm{I}_{\mathrm{geo}}$ classes for the 7 studied heavy metals for each location are listed in Tables 4 and 5. The $\mathrm{I}_{\text {geo }}$ values revealed that nearly all the locations for $\mathrm{Ni}$ respectively fell into 
classes 2 and 3. The $\mathrm{I}_{\text {geo }}$ values for $\mathrm{Pb}$ (with the exception Iweka, Niger and Moore) and Fe were in class 0 revealing that the studied soils were not polluted by these two metals in both seasons. The I geo values for $\mathrm{Mn}$ in all locations (except Venn Road, Creek/Okwaraji and Bida which were in class 4) were in class 5 in wet season while in dry season Mn was mainly in class 4 with the exceptions of Modebelu, Port Harcourt and Iweka which were in class 3 while Oguta was in class 2 in dry season confirming that other locations were strongly polluted by $\mathrm{Mn}$ in dry season while in wet season, the range is between 4 and 5 class for all locations. It showed that all locations in wet season were strongly to extremely polluted by Mn

Table 5. Geo-accumulation index classes for seven metals in dry season.

\begin{tabular}{llllllll}
\hline Location & Mn & Ni & Zn & $\mathbf{C r}$ & $\mathbf{C u}$ & $\mathbf{P b}$ & $\mathbf{F e}$ \\
\hline Modebelu Avenue & 3 & 2 & 1 & 5 & 3 & 0 & 0 \\
Ozomagana & 4 & 2 & 2 & 5 & 2 & 0 & 0 \\
Ziks Avenue & 4 & 2 & 2 & 5 & 2 & 0 & 0 \\
Port Harcourt Rd & 3 & 0 & 2 & 5 & 2 & 0 & 0 \\
Oguta Rd & 2 & 1 & 2 & 5 & 2 & 0 & 0 \\
Iweka Rd & 3 & 2 & 2 & 5 & 4 & 1 & 0 \\
Venn Rd & 4 & 2 & 2 & 5 & 0 & 0 & 0 \\
Niger Street & 4 & 3 & 2 & 5 & 3 & 1 & 0 \\
CreekOkwaraji street & 4 & 2 & 2 & 4 & 0 & 0 & 0 \\
Moore street & 4 & 3 & 2 & 4 & 3 & 1 & 0 \\
Bida Rd & 4 & 2 & 2 & 5 & 0 & 0 & 0 \\
Mean & 3 & 2 & 2 & 5 & 2 & 0 & 0 \\
\hline
\end{tabular}

$\mathrm{I}_{\mathrm{geo}}=$ geoaccumulation index for wet season

$\mathrm{Ni}$ (except for Port Harcourt road which was in class 0 and Oguta road which was in class 1 in both seasons) was between class 3 and 2 for all locations in both seasons showing that $\mathrm{Ni}$ moderately to strongly polluted the area in both seasons in the locations indicated. The $\mathrm{I}_{\text {geo }}$ values for $\mathrm{Zn}$ in all locations (except in Modebelu Avenue which was in class 0 in wet season) was in the range of class 1 to 2 which indicated that in both seasons $\mathrm{Zn}$ unpolluted to moderately polluted the studied area. The $\mathrm{Cu}$ Igeo values varied mostly, ranging from class 0 to 4 with Iweka road having the highest (class 4) in dry season showing that $\mathrm{Cu}$ strongly to extremely polluted Iweka road in dry season. Most stations fell into class 4 and 5 for $\mathrm{Cr}$ indicating that the heavy metal strongly to extremely polluted the whole area in both seasons.

It implied that Mn strongly to extremely polluted the soil in wet season and moderately to strongly polluted the soil in dry season. Cr also strongly - extremely polluted soil in both seasons, while $\mathrm{Cu}, \mathrm{Ni}$ and $\mathrm{Zn}$ moderately polluted soil in both seasons. The soils are unpolluted with $\mathrm{Fe}$ and $\mathrm{Pb}$ in both seasons. The values obtained are relatively lower than that obtained by Jiang et al. (2013) [14].
According to the mean $I_{\text {geo }}$ values, contamination levels of heavy metals were in the increasing order of $\mathrm{Fe}<\mathrm{Pb}$ $<\mathrm{Zn}<\mathrm{Cu}<\mathrm{Ni}<\mathrm{Cr}<\mathrm{Mn}$ and $\mathrm{Fe}<\mathrm{Pb}<\mathrm{Zn}<\mathrm{Ni}<\mathrm{Cu}<\mathrm{Mn}<\mathrm{Cr}$ in both wet and dry seasons respectively.

\subsection{Correlation and PCA on the Heavy Metals}

Correlation and Principal component Analysis were used to provide information on the sources of heavy metal in the soil. The results were presented in the Table 6 . There were no significant correlation among the heavy metals studied suggesting that they are not from the same anthropogenic sources. Additionally, seven principal components (PC1..... PC7) with eigenvalues higher than 1.0 were extracted from the PCA. PC1..... PC7. The principal components values are the loadings and the column wise, sum of the squares of the loadings is 1 i.e. (for instance: PC1, there are $-0.5140^{2}+$ $0.2131^{2}+0.2204^{2}+\ldots .+0.5481^{2}$ ).

The associated eigenvalues add up to the sum of the variances of the variables in the analysis ( 7 in this case) i.e. the "total variance" of the variables. Because of analysis of correlation matrix, the variables are standardized to have unit variance, so the total variance is 7 . The eigenvalues are the variances of the principal components. The first principal component has variance 2.264 , explaining 32\% (2.264/7) of the total variance and so on.

Looking more closely at the principal components, we observe for instance that the third component has positive loadings in the first four heavy metals (Mn, Ni, $\mathrm{Zn}$ and $\mathrm{Cr}$ ) and negative loadings in the last three heavy metals $(\mathrm{Cu}, \mathrm{Pb}$ and $\mathrm{Fe}$ ). This implies that for the positive loadings, the extent of the heavy metals on the sampling sites is high while the negative loadings suggests otherwise. It can be interpreted that the sources of heavy-metal pollution in $\mathrm{Mn}, \mathrm{Ni}, \mathrm{Zn}$ and $\mathrm{Cr}$ are different from the sources of heavy-metal pollution in $\mathrm{Cu}, \mathrm{Pb}$ and Fe. Also, the extent of heavy metal concentration is more in the former (positive loadings) than in the later (negative loadings). This implies that the metals are not from the same anthropogenic source. Industrial and human activities in the area involving electrical wiring, various alloys, alloys, pigments, fungicides, insecticides, electroplating, cooking utensils, batteries and dye production are the possible sources of $\mathrm{Cu}$ and $\mathrm{Cr}$. When these products are thrown into the dumpsite, these elements are leached away and accumulate at the top soil where they are adsorbed because of affinity for metals by organic matter $[15 ; 16 ; 17 \& 18)$.

Correlation using Varimax

Table 6 shows correlation and principal component analysis using Varimax rotated component matrix for total extractable

Table 6. Varimax rotated component matrix for total extractible.

\begin{tabular}{|c|c|c|c|c|c|c|c|c|}
\hline \multirow{2}{*}{ Location } & \multicolumn{7}{|c|}{ Extracted components } & \multirow{2}{*}{ Eigenvalue } \\
\hline & Comp 1 & Comp 2 & Comp 3 & Comp 4 & Comp 5 & Comp 6 & Comp 7 & \\
\hline $\mathrm{Mn}$ & -0.5140 & 0.2132 & 0.2607 & 0.4568 & 0.1469 & 0.4508 & 0.4346 & 2.264 \\
\hline $\mathrm{Ni}$ & 0.2131 & 0.5287 & 0.4491 & 0.4569 & -0.0651 & -0.3713 & -0.3499 & 1.79946 \\
\hline $\mathrm{Zn}$ & 0.204 & -0.3194 & 0.4336 & -0.0648 & 0.7109 & 0.2629 & -0.2877 & 1.215599 \\
\hline $\mathrm{Cr}$ & 0.5671 & 0.4253 & 0.2072 & -0.3834 & -0.0415 & 0.2544 & 0.4910 & 0.698088 \\
\hline
\end{tabular}




\begin{tabular}{llllllll}
\hline \multirow{2}{*}{ Location } & \multicolumn{2}{l}{ Extracted components } & & & & \\
\cline { 2 - 7 } & Comp 1 & Comp 2 & Comp 3 & Comp 4 & Comp 5 & Comp 6 & Comp 7 \\
\hline $\mathrm{Cu}$ & -0.0397 & 0.3963 & -0.5084 & 0.0131 & 0.6787 & -0.3163 & 0.1485 \\
$\mathrm{~Pb}$ & 0.1350 & 0.3172 & -0.4212 & 0.1118 & -0.0797 & 0.6518 & -0.5100 \\
$\mathrm{Fe}$ & 0.5481 & -0.3667 & -0.2520 & 0.6470 & -0.0111 & 0.0148 & 0.2876 \\
\% of Variance & 32.342 & 25.706 & 17.942 & 9.972 & 9.495 & 3.137 & 0.0981153 \\
\hline
\end{tabular}

Method: Principal components/correlation

Rotation: orthogonal varimax (Kaiser Normalization on)

Number of obs $=11$

Number of comp. $=7$

Source: STATA 11 Computations

\section{Conclusion}

The soils of Onitsha South LGA are unpolluted with $\mathrm{Cd}, \mathrm{Fe}$ and $\mathrm{Pb}$ but are polluted at various levels with $\mathrm{Cr}, \mathrm{Mn}, \mathrm{Ni}$ and $\mathrm{Zn}$ in both seasons. The pollution level in dry season is higher than the wet season which is due to increase in leaching by acid rain during rainy season and dilution by large volume of water.

\section{Acknowledgements}

The research work was done using some the equipment provided by research laboratory of Pure and Industrial Chemistry Department of Nnamdi Azikiwe University, Awka. We thank our colleagues from the same department who provided insight and expertise that greatly assisted this research.

We thank Prof Vincent Ajiwe of the same institution for assisting with methodology and technique used in this work and for comments that greatly improved the manuscript.

\section{References}

[1] M. K. Zhang, Z. Y. Liu, and H. Wang. "Use of single extraction method to predict bioavailability of heavy metals in polluted soils to rice' Communicationsin soil scince and Plant Analysis, vol 41, no, 7, pp 820-831, 2010.

[2] B. Dousova, F. Buzek, J. Rothwell, S. Krejcova and M. Lhotka. Adsorption behavior of arsenic relating to different natural solids: soils, stream sediments and peats. Science Total Environment. Sep 12012 [cited 2018 Jun 21]; 433: 456-61.

[3] M. Bhuiyan, M. A. Islam and S. B. Dampare. (2010). Evaluation of hazardous metals pollution in irrigation and drinking water systems in the vicinity of a coal mine area of north western Bangladesh. Journal of hazardous materials. 179 (1-3): 1065-77.

[4] G. Shi, Z. Chen, C. Bi, Y. Li, J. Teng, L. Wang, and S. Xu. (2010). Comprehensive assessment of toxic metals in urban and sub urban street depodited sediments (SDSs) in the biggest metropolis area of China. Environmental pollution 158; 764-771.

[5] Guo P, Xie ZL, Li J, Kang CL, Liu JH (2005) Relationships between fractionations of $\mathrm{Pb}, \mathrm{Cd}, \mathrm{Cu}, \mathrm{Zn}$ and $\mathrm{Ni}$ and soil properties in urban soils of Changchun, China. Chinese Geographical Science 15: 179-185.

[6] Liao F, Zhou S, Zhang H, Wu S, Zhao Q (2008) Spatial distribution and changes of heavy metals of agricultural lands in typical pregrading coast in Dongtai City, Jiangsu province,
China. Chinese Geographical Science 18: 276-283.

[7] J. O, Ejikeme, J. I. Igbokwe, E. C Igbokwe andI. C. Ezeomedo. (2014). The Revision of 1:50000 Topographic Map of Onitsha Metropolis, Anambra State, Nigeria Using Nigeriasat-1 imagery. International journal of Engineering and Management science 5 (4): 235-240.

[8] Akanni, C. O. (1992). Climate. In: Onakomaya, S. O, Oyesiku, $\mathrm{K}$, jegede, $\mathrm{j}$, editors. Ogun state in maps. Ibadan: Rex Charles Publisher: p 187.

[9] D. Dilek, and A. Ahmet. (2006). Heavy Metal levels in Vegetables in Turkey are within safe limits for $\mathrm{Cu}, \mathrm{Zn}$ and $\mathrm{Ni}$ and exceeded for $\mathrm{Cd}$ and $\mathrm{Pb}$. Journal of Food Quality, 29: 3.

[10] Omuku, P. E (2011). Speciation patterns of selected heavy metals in the top soils of roadside gutters within twenty four major towns of Anambra State, Nigeria, pp. 105-133.

[11] Jiang, M., Zeng, G,. Zhang, C., Ma, X., Chen, M and Zhang, J. (2013). Assessment of Heavy Metal Contamination in the surrounding Soils and Surface Sediments in Xiawangang River, Qingshuuitang District, 8 (8): 71176.

[12] Amadi, A. N., Assessing the Effects of Aladimma Dumpsite on Soil and Groundwater Using Water Quality Index and Factor Analysis, Aust. J. Basic Appl. Sci., 2011, no. 5 (11), pp. 763-770.

[13] Odero, D. R., Semu, E., and Kamau, G., Assessment of cottage industries-derived heavy metal pollution of soil within Ngara and Gikomba area of Nairobi city, Kenya, Afri. J. Sci. Technol., 2000, no. 1 , pp. 52-62.

[14] Rayment, G. E., and Higginson, F. R., Australian Laboratory Handbook of soil and water chemical methods, Port Melbourne: Reed International books Australia P/L, trading as Inkata Press, 1992

[15] Linnik, P. M., and Zubenko, I. B., Role of bottom sediments in the secondary pollution of aquatic environments by heavy metal compounds, lakes and reservoirs. Res. Manage. 2000, no. 5, pp. 11-21.

[16] Campbell, L. M., Mercury in Lake Victoria (East Africa): Another emerging issue for a Beleaguered Lake? Ph.D. dissertation, Waterloo, Ontario, Canada, 2001.

[17] Lwanga, M. S., Kansiime, F., Denny, P., and Scullion, J., Heavy metals in Lake George, Uganda with relation to metal concentrations in tissues of common fish specie, Hydrobiologia, 2003, no. 499, pp. 83-93.

[18] Gupta, S., Jena V., Matić N., Kapralova V and Solanki, J. (2014). Assessment of geo-accumulation index of heavy metal and source of contamination by multivariate factor analysis. International journal of hazardous materials, Vol 2, pp 18-22 